\title{
Christo van Rensburg (1938-2018): akademikus van formaat
}

\section{Heinrich Ohlhoff}

Heinrich Ohlhoff is 'n emeritus-professor en was voorheen verbonde aan die Departement Afrikaans, Universiteit van Pretoria.

E-pos: ohlhoff@icon.co.za

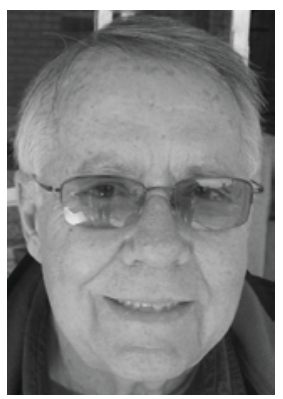

Dosent en studieleier, departementshoof, akademikus, navorserso sou'n mens prof. M. C. J. (Christo) van Rensburg se professionele loopbaan met 'n paar breë kwashale kom karakteriseer.

Christo, wat gepromoveer het met die proefskrif Die struktuur van die sin in Afrikaans: 'n ontleding van bepaalde patrone teen die agtergrond van die huidige teorieë oor die transformasioneel-generatiewe grammatika, het aan die Universiteit van Pretoria, sy alma mater, as dosent begin. Hier het sy studente wat, in meer as een geval, latere kollegas sou word, onder meer deur sy toedoen algaande kennis gemaak met verskillende jonger rigtings in die taalwetenskap: die linguistiese stilistiek, die TGG, die sosiolinguistiek, e.d.m. Hy het ook meegewerk om vernuwende onderrig-leerstrategieë in te voer soos die gebruik van werkboeke en volgstukke met oop ruimtes vir aantekeninge.

Ná 'n relatief kort akademiese tyd aan die Universiteit van die Vrystaat, keer hy terug na Tukkies waar hy prof. Réna Pretorius later as departementshoof opvolg. As studieleier van $\mathrm{M}$ - en D-studente was hy rigtinggewer, begeleier en raadgewer en as departementshoof het hy nie net akademiese en bestuursleiding verskaf nie maar ook as simpatieke mentor vir veral jonger kollegas opgetree. Voor sy aftrede het hy verder 'n rol gespeel in die totstandkoming van UP se Eenheid en vir Akademiese Geletterdheid waarvan hy die eerste direkteur was.

In die April 2018-nuusbrief van die Suid-Afrikaanse Akademie word o.m. geskryf dat Christo "se hele loopbaan... in diens van Afrikaans gestaan [het] en danksy hom het verskeie uiters belangrike sienings oor die taal as studieterrein en oor die taal se herkoms na vore gekom." Sy grootste bydrae lê dan ook waarskynlik op navorsingsgebied, spesifiek oor o.m. die variëteite van Afrikaans wat hy geïdentifiseer en nagevors het (Oranjerivier-, Kaapse en Oosgrens-Afrikaans) en die tekens van "Afrikaans" wat tot vóór 1652 nagespoor kan word met die ontmoetings van Nederlandse seevaarders en Khoi-sprekers aan die Kaap. Daarmee het hy ook die grondslag gelê vir verdere navorsing waardeur bepaalde uitgangspunte en gevolgtrekkings gekwalifiseer en verfyn is. 
Hierdie navorsing het in verskillende wetenskaplike en ook meer populêre publikasies neerslag gevind. So was daar byvoorbeeld in 1995 "Afrikaans se Kreoolse status" wat in 'n Man van woorde. Feesbundel vir Louis Eksteen verskyn het, en in 2016 "Die vroegste Khoi-Afrikaans" in Tydskrif vir Geesteswetenskappe. Primêr vir algemene lesers en voorgraadse studente bedoel is weer Taalvariëteite en die wording van Afrikaans in Afrika (1990) met sy klem, reeds in die titel, op Afrikaans as taal van Afrika, en So kry ons Afrikaans (2012). Laasgenoemde is in opdrag van die Afrikaanse Taalraad geskryf met die doel dat die storie oor die herkoms van Afrikaans opnuut nagevors sou word en die gedeelde geskiedenis van Afrikaans en sy sprekers vertel kon word. So is daar wegbeweeg van 'n verdelende taalgeskiedenis. Na wat berig word, wou prof. Van Rensburg op die dag van sy dood nog die hersiene uitgawe van dié publikasie finaal afrond.

Christo was lank lid van die Taalkommissie van die Akademie-verantwoordelik vir die samestelling en hersiening van die Afrikaanse woordelys en spelreëls—en daarom was dit gepas dat hy teen die einde van 2017 die Hertzog-gedenklesing gelewer het met die titel "Toe die maak van die Afrikaanse woordelyste \& spelreëls ook perdekoop was."

Erkenning vir sy baanbrekerswerk op die gebied van die Afrikaanse (historiese) taalkunde en die bevordering van en diens ten behoewe van Afrikaans in sy verskillende geledinge het, soos te verwagte, nie uitgebly nie. In 2001 het Taallandskap: huldigingsbundel vir Christo van Rensburg verskyn en in 2018 is sowel die C.J. Langenhovenprys vir Taalwetenskap as die Jan H. Maraisprys vir 'n uitnemende bydrae tot Afrikaans as wetenskapstaal aan hom toegeken.

In sy omgang met mense-vriende, kollegas, studente-was Christo, sover dit van hom afgehang het, vriendelik, tegemoetkomend en het hy nooit uit die hoogte opgetree nie. Tiperend hiervan was die feit dat hy, toe ons-sy studente van kort tevore-sy kollegas geword het, nie wou hoor dat ons hom op sy titel aanspreek nie.

Christo van Rensburg: akademikus van formaat—ons eer sy nagedagtenis.

20 Augustus 2018

Pretoria 